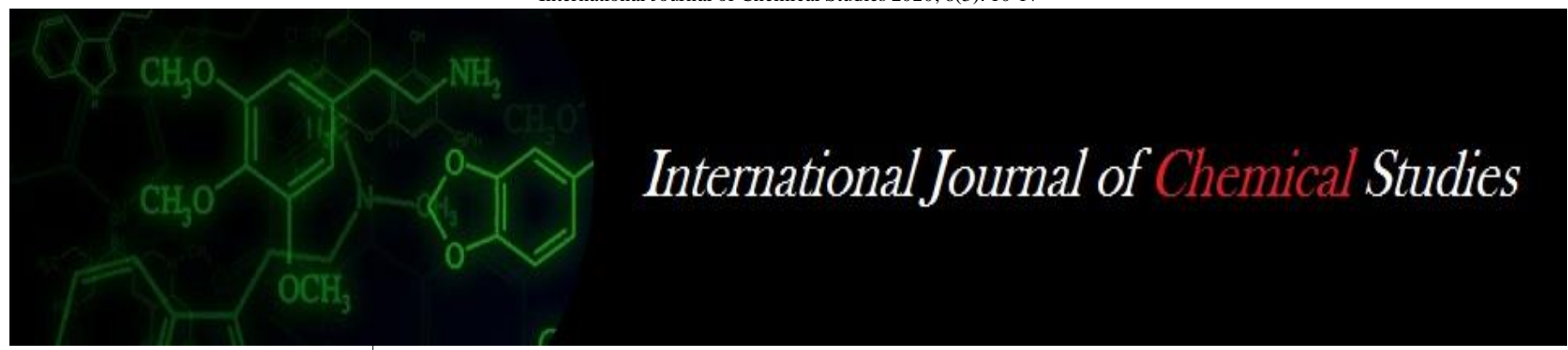

P-ISSN: 2349-8528

E-ISSN: 2321-4902

www.chemijournal.com

IJCS 2020; 8(3): 10-17

(C) 2020 IJCS

Received: 08-03-2020

Accepted: 10-04-2020

Biswajit Lenka

Research Scholar, Indian

Institute of Technology,

Kharagpur, West Bengal, India

Divya RK

Scientific Officer, International

Crops Research Institute for

Semi- arid Tropics, Hyderabad,

Telangana, India

Das SK

Assistant Professor, Bidhan

Chandra Krishi

Vishwavidyalaya, Mohanpur,

Bihar, India
Corresponding Author: Biswajit Lenka

Research Scholar, Indian Institute of Technology,

Kharagpur, West Bengal, India

\section{Nutrient use effeciency, yield attributes and comparative economics of potato crop (Solanum tuberosum L.) in response to zinc and boron nutrition in entisols of India}

\author{
Biswajit Lenka, Divya RK and Das SK
}

DOI: https://doi.org/10.22271/chemi.2020.v8.i3a.9457

\begin{abstract}
A field experiment was conducted during the winter (rabi) seasons of 2015-16 and 2016-17 at C-unit research farm of Bidhan Chandra Krishi Viswavidyalaya, Kalyani, Nadia, West Bengal, India to determine the effect of boron and zinc on growth and yield of potato under lower Gangetic plains of West Bengal. The experiment was laid out in a randomized block design with four replications having seven treatments viz. T1 (RDF of NPK 200:150:150 kg N: P2O5:K2O/ha), T2 (T1+2.0 kg B/ha as soil application), T3 (T1+ $4.5 \mathrm{~kg} \mathrm{Zn} / \mathrm{ha}$ as soil application), T4 $(\mathrm{T} 1+2.0 \mathrm{~kg} \mathrm{~B} / \mathrm{ha}$ and $4.5 \mathrm{~kg} \mathrm{Zn} / \mathrm{ha}$ as soil application), T5 (T1 $+0.1 \%$ boron (boric acid) as foliar application in three times at 40, 50 and 60 DAP), T6 (T1+ 0.1\% zinc (zinc sulphate) as foliar application in three times at 40, 50 and 60 DAP) and T7 (T1+ Foliar spray of $0.1 \%$ zinc (zinc sulphate) $+0.1 \%$ boron (boric acid) at 40,50 and 60 DAP). The soil of the experimental field was sandy loam in texture and slightly alkaline in reaction $(\mathrm{pH} 7.35)$ having an organic carbon content of $0.57 \%, 183.26 \mathrm{Kg}$ available $\mathrm{N} / \mathrm{ha}, 16.80 \mathrm{~kg}$ available $\mathrm{P} / \mathrm{ha}, 132.00 \mathrm{~kg}$ available $\mathrm{K} / \mathrm{ha}$. The available $\mathrm{Zn}$ and $\mathrm{B}$ content of initial soil were $1.48 \mathrm{mg} / \mathrm{kg}$ and $0.86 \mathrm{mg} / \mathrm{kg}$ respectively. The results revealed that the highest values of various nutrient use and uptake efficiency parameters were recorded with the foliar application of $\mathrm{Zn}$ and $\mathrm{B}$. Also, the same trend was observed where the highest value of harvest index of $83.20 \%$ and returns per rupee invested above farmeres practice of $28.5 \%$ was observed in $\mathrm{T} 7$ (T1+ Foliar spray of $0.1 \%$ zinc (zinc sulphate) $+0.1 \%$ boron (boric acid) at 40,50 and 60 DAP).
\end{abstract}

Keywords: Nutrient use efficiency, harvest index, returns per rupee of investment above farmer"s practice

\section{Introduction}

Potato (Solanum tuberosum L.) as a member of the family Solanaceae is one of the most important food crops all over the world and is an important food crop grown in more than 150 countries in the world. Potato popularly known as 'The King of Vegetables' has emerged as fourth most important food crops in India after rice, wheat and maize. In Indian agriculture, potato being a cash crop, occupies a unique position due to its high nutritional value and protein quality as compared to that of cereals. Potatoes are heavy nutrient requiring crop because of their bulk yields within a short time having shallow root systems. In potato cultivation, some elements like $\mathrm{Zn}, \mathrm{B}, \mathrm{S}$, and $\mathrm{Mg}$ can help in increasing the foliage coverage at initial growth stages and in the later stages, the translocation of assimilates is responsible for higher yield (Trehan and Grewal, 1981) ${ }^{[25]}$. It is a nourishing and wholesome food \& plays a pivotal role in the farm economy.

Use of high analysis fertilizers and intensive cropping has led to deficiency of many secondary micronutrients in areas where crop intensity is high. Availability of $\mathrm{Zn}$ to plant is hampered by its immobile nature and adverse soil conditions. Thus, $\mathrm{Zn}$ deficiency is observed even though high amount is available in soil. Root-shoot barrier, a major controller of zinc transport in plant is highly affected by changes in the anatomical structure of conducting tissue and adverse soil conditions like $\mathrm{pH}$, clay content, calcium carbonate content, etc. $\mathrm{Zn}$ deficiency results in severe yield losses and in acute cases plant death. Zn deficiency in edible plant parts results in micronutrient malnutrition leading to stunted growth and improper sexual development in 
humans. $\mathrm{Zn}$ is inimitable element in several plant metabolic processes such as enzyme activation like RNA polymerases, superoxide dismutase, alcohol dehydrogenase, carbonic anhydrase, protein synthesis and metabolism of carbohydrate, lipid and nucleic acid (Cakmak 2000; Palmer and Guerinot 2009) ${ }^{[1,19]}$. Also $\mathrm{Zn}$ ions are integral parts of $\mathrm{Zn}$ finger family of transcription factors controlling cell proliferation and differentiation (Palmer and Guerinot 2009) ${ }^{[19]}$. Besides these, $\mathrm{Zn}$ plays major role in chloroplast development and function, of which most important are the Zn-dependent activity of SPP peptidase and the repair process of photo system II by turning over photo-damaged D1 protein (Hansch and Mendel 2009) [11]. Thus cells need mechanisms for maintaining Zinc homeostasis when available supplies decrease (Eide, 2009) ${ }^{[7]}$. In plants, $\mathrm{Zn}$ deficiency reduces growth, tolerance to stress and chlorophyll synthesis (Kawachi et al. 2009; Lee et al. 2010) ${ }^{[13,14]}$.

Experiments have indicated that Zinc is most deficient micronutrient in potato grown soil followed by iron, copper, and manganese. Zinc is directly or indirectly required by several enzyme systems, auxins and in protein synthesis, seed production and rate of maturity. Zinc is believed to promote RNA synthesis, which in turn is needed for protein production. $\mathrm{Zn}$ is known to have an important role either as a metal component of enzymes or as a functional, structural or regulatory cofactor of a large number of enzymes (Grotz and Guerinot 2006) ${ }^{\text {[9] }}$. Zinc plays a key role in hormone biosynthesis, structural stability of organelles, cytochrome c synthesis, activation and proper function of a number of enzymes, protein synthesis, stability and integrity of the root cell plasma membrane.

Boron (B) is a micronutrient necessary for plant growth. It plays an important roles in cell wall synthesis, sugar transport, cell division, cell development, auxin metabolism, good pollination and fruit set, seed development, synthesis of amino acids and proteins, nodule formation in legumes and regulation of carbohydrate metabolism. Boron deficiencies occur over a much wide range of soils and crops than do deficiencies are found most often in light soils, low organic matter contents and high soil pH levels (Mengel and Kirkby, 1978) ${ }^{[17]}$. Because of its role in fertilization and flowering processes of crops, $\mathrm{B}$ is being given special importance. If it is deficient, one of the first adverse effects is on flowering and fruiting and therefore, on the yield and quality of the crops. Adverse effects on the yield can occur even though no deficiency symptoms are evident on the foliage and it is known as hidden hunger. Boron deficiency is often an unsuspected enemy of crop production.

Boron is the micronutrient needed in the greatest quantity to ensure several key growth processes. It influences root and shoot growth, plant development and pollination. Alongside
Potassium, Calcium and Magnesium, Boron is an important element present in the cell wall. Here, it acts as a cementing agent between pectins, providing cohesive strength for cell tissues. Therefore, Boron affects tuber storage quality characteristics. Boron also affects Calcium absorption, so supplies are important to ensure a balanced nutrition. Boron deficiency severely inhibits pollen germination and pollen tube growth as well as the viability of pollen grains (Dugger, 1973) [5]. Boron is unique among the essential mineral nutrients. It is the only element that is normally present in soil solution as non-ionized molecule over the $\mathrm{pH}$ range suitable for the plant growth.

\section{Materials and methods \\ Experimental site}

The field experiment was conducted during the winter ( $r a b i)$ seasons of 2015-16 and 2016-17 to study the effect of Boron and Zinc application on growth and productivity of potato under lower Gangetic plains of West Bengal at C-Unit Research Farm (Kalyani) of Bidhan Chandra Krishi Viswavidyalaya, Nadia, West Bengal. The farm is situated at $22^{\circ} 58^{\prime} \mathrm{N}$ latitude and $88^{\circ} 25^{\prime} \mathrm{E}$ longitudes with an elevation of $9 \mathrm{~m}$. above mean sea level and the ecosystem was medium land. The experiment was laid out in the field which has homogeneous fertility and uniform textural make-up, and was well connected to an electric pump through an earthen irrigation channels for frequent and timely irrigation.

\section{Edaphic conditions}

Experimental field at C-Unit, BCKV, Kalyani lies in the IndoGangetic alluvial plains. The alluvial soils (Inceptisols) are deep, moderately fertile with adequate internal drainage. The composite samples from 0-30 cm. Depth were randomly collected from five places in the experimental field with the help of screw auger prior to know the initial fertility status of the experimental field. All the possible technical precautions as prescribed for standard soil sampling were also taken. Then soil samples were brought to the laboratory, air-dried and ground, thereafter sieved through 80 meshes. The soil samples thus obtained were subjected to various physical and chemical analyses, and the results obtained have been presented in Table 1.

Table 1: Physico-chemical properties of experimental soil

\begin{tabular}{|c|c|c|}
\hline Particulars & Values & Methods Used \\
\cline { 1 - 2 } Mechanical Composition & & International \\
1. Sand (\%) & 27.40 & Pipette Method \\
2. Silt (\%) & 44.40 & 28.20 \\
3. Clay (\%) & (Piper, 1966) ${ }^{[20]}$ \\
\hline 4. Texture & Sandy Loam & \\
\hline
\end{tabular}

\section{Chemical composition}

\begin{tabular}{|c|c|c|}
\hline 1. Soil pH & 7.35 & Beckman's pH meter method in 1:2.5 soil:water sample (Jackson, 1967) ${ }^{[12]}$ \\
\hline 2. Organic Carbon $(\%)$ & 0.57 & Walkley \& Black method (Jackson, 1967) ${ }^{[12]}$ \\
\hline 3. Total Nitrogen $\left(\mathrm{kg} \mathrm{ha}^{-1}\right)$ & 183.26 & Modified Kjeldal Method (Jackson, 1967) ${ }^{[12]}$ \\
\hline 4. Available $\mathrm{P}\left(\mathrm{kg} \mathrm{ha}^{-1}\right)$ & 16.80 & Olsen's Method (Jackson, 1967) ${ }^{[12]}$ \\
\hline 5. Available $\mathrm{K}\left(\mathrm{kg} \mathrm{ha}^{-1}\right)$ & 132.00 & Flame Photometer Method (Jackson, 1967) ${ }^{[12]}$ \\
\hline 6. Available $\mathrm{Zn}\left(\mathrm{mg} \mathrm{kg}^{-1}\right)$ & 1.48 & 0.005 M DTPA solution adjusted to pH 7.3 (Soil:extractant::1:2) (Lindsay and Norvell,1978) ${ }^{[15]}$. \\
\hline 7. Available $\mathrm{B}\left(\mathrm{mg} \mathrm{kg}^{-1}\right)$ & 0.86 & $\begin{array}{l}\mathrm{Hot}_{\mathrm{CaCl}} \text { extractant (Soil:extractant::1:2) and the amount of Boron extracted was determined by the } \\
\text { Azomethine }-\mathrm{H} \text { method of Wolf }(1971)^{[28]} \text { with slight modification as suggested by Gupta (1979) }{ }^{[10]} \text {. }\end{array}$ \\
\hline
\end{tabular}


Table 2: Treatment details

\begin{tabular}{|c|c|c|}
\hline Treatments & & Treatment Details \\
\hline $\mathrm{T}_{1}$ & $:$ & RDF of NPK (200:150:150 kg N: $\left.\mathrm{P}_{2} \mathrm{O}_{5}: \mathrm{K}_{2} \mathrm{O} / \mathrm{ha}\right)$ \\
\hline $\mathrm{T}_{2}$ & $:$ & $\mathrm{T}_{1}+2.0 \mathrm{~kg} \mathrm{~B} / \mathrm{ha}$ as soil application \\
\hline $\mathrm{T}_{3}$ & $:$ & $\mathrm{T}_{1}+4.5 \mathrm{~kg} \mathrm{Zn} / \mathrm{ha}$ as soil application \\
\hline $\mathrm{T}_{4}$ & $:$ & $\mathrm{T}_{1}+2.0 \mathrm{~kg} \mathrm{~B} / \mathrm{ha}$ and $4.5 \mathrm{~kg} \mathrm{Zn} / \mathrm{ha}$ as soil application \\
\hline $\mathrm{T}_{5}$ & 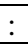 & $\mathrm{T}_{1}+0.1 \%$ boron (boric acid) as foliar application in three times at 40,50 and 60 DAP \\
\hline $\mathrm{T}_{6}$ & 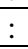 & $\mathrm{T}_{1}+0.1 \%$ zinc (zinc sulphate) as foliar application in three times at 40,50 and $60 \mathrm{DAP}$ \\
\hline $\mathrm{T}_{7}$ & $:$ & $\mathrm{T}_{1}+$ Foliar spray of $0.1 \%$ zinc (zinc sulphate) $+0.1 \%$ boron (boric acid) at 40,50 and 60 DAP \\
\hline
\end{tabular}

\section{Calculation of nutrient uptake}

The uptake of major nutrient elements like N,P,K and minor nutrient elements like $\mathrm{Zn}$ and $\mathrm{B}$ from each plot of potato was worked out on dry weight basis by multiplying the dry matter (DM) yield of the crops with corresponding content of nutrient element:

Uptake $(\mathrm{kg} / \mathrm{ha})=$ Concentration $(\%) \mathrm{X}$ Yield $(\mathrm{kg} / \mathrm{ha})$

\section{Estimation of Zinc in plant sample}

Plant samples digested with tri acid mixture of $\mathrm{HNO}_{3}: \mathrm{H}_{2} \mathrm{SO}_{4}: \mathrm{HClO}_{4}$ in the ratio $10: 1: 4$ as described by Jansen (1978). After digestion it was cooled and filtered \& then concentration of $\mathrm{Zn}$ was measured by an Atomic Adsorption Spectrophotometer by running standard.

\section{Estimation of Boron in plant sample}

Plant B was estimated by muffling of dried plant sample at $550^{\circ} \mathrm{C}$. After cooling $\mathrm{H}_{2} \mathrm{SO}_{4}$ was added to it \& later Ammonium acetate buffer ( $\mathrm{pH} 5.5$ ) and $0.025 \mathrm{M}$ EDTA were added to it. After adding $0.9 \%$ Azomethine-H, solution the tube was vortexed and the reading was taken using Spectrophotometer at $420 \mathrm{~nm}$ reading.

\section{Nutrient use efficiency \\ Partial factor productivity}

Partial factor productivity (PFP) is a measure of efficiency of input use (Cassman et al., 1998) ${ }^{[2]}$. It is calculated as a ratio of the economic yield of the crop to the amount of nutrient applied.

$$
\mathrm{PFP}=\frac{\text { Tuber yield of potato }(\mathrm{kg} / \mathrm{ha})}{\text { Amount of nutrient applied }(\mathrm{kg} / \mathrm{ha})}
$$

\section{Agronomic efficiency}

Agronomic efficiency (AE) is expressed as the increase in the yield of the crop for every incremental application of a particular nutrient in comparison to that of the control (Novoa and Loomis, 1981) ${ }^{[18]}$.

$$
\mathrm{AE}=\frac{\text { Tuber yield in treatment }(\mathrm{kg} / \mathrm{ha})-\text { Tuber yield in control }(\mathrm{kg} / \mathrm{ha})}{\text { Nutrient applied in treatment }(\mathrm{kg} / \mathrm{ha})-\text { Nutrient applied in control }(\mathrm{kg} / \mathrm{ha})}
$$

\section{Uptake efficiency}

Uptake efficiency (UE) is the measure of the percentage of the total plant nutrient uptake in a particular treatment versus that of control to the amount of nutrient applied in the treatment (Cassman et al., 1998) ${ }^{[2]}$.

$$
\mathrm{UE}=\frac{\text { Nutrient upatke in treatment }(\mathrm{kg} / \mathrm{ha})-\text { Nutrient upatke in control }(\mathrm{kg} / \mathrm{ha})}{\text { Nutrient applied in treatment }(\mathrm{kg} / \mathrm{ha})} \times 100
$$

\section{Biomass nutrient use efficiency}

Biomass nutrient use efficiency (BNUE) is the measure of the percentage of total biomass yield in the treated plot versus that in control to the difference in nutrient uptake between that of treated and control plots (Cassman et al., 1998) ${ }^{[2]}$.

$$
\mathrm{BNUE}=\frac{\text { Biomass yield in treatment }(\mathrm{kg} / \mathrm{ha})-\text { Biomass yield in control }(\mathrm{kg} / \mathrm{ha})}{\text { Nutrient uptake in treatment }(\mathrm{kg} / \mathrm{ha})-\text { Nutrient uptake in control }(\mathrm{kg} / \mathrm{ha})} \times 100
$$

\section{Physiological nutrient use efficiency}

Physiological nutrient use efficiency (PNUE) is the measure of the percentage of total tuber yield in the treated plot versus that in control to the difference in nutrient uptake between that of treated and control plots (Craswell and Godwin, 1984) [3].

$$
P N U E=\frac{\text { Tuber yield in treatment }(\mathrm{kg} / \mathrm{ha})-\text { Tuber yield in control }(\mathrm{kg} / \mathrm{ha})}{\text { Nutrient uptake in treatment }(\mathrm{kg} / \mathrm{ha})-\text { Nutrient uptake in control }(\mathrm{kg} / \mathrm{ha})} \times 100
$$

\section{Recovery efficiency}

Recovery efficiency (RE) is the percentage of the difference between nutrient uptake in the treated and control plots over the amount of nutrient applied (Craswell and Godwin, 1984) ${ }^{[3]}$.

$$
\mathrm{RE}=\frac{\text { Nutrient uptake in treatment }(\mathrm{kg} / \mathrm{ha})-\text { Nutrient uptake in control }(\mathrm{kg} / \mathrm{ha})}{\text { Amount of nutrient applied }(\mathrm{kg} / \mathrm{ha})} \times 100
$$

\section{Yield attributes}

\section{Total dry matter production}

For recording dry matter accumulation, one plant from the penultimate row in each plot were uprooted carefully and then sun-dried. After sun drying, the plant sample was separated into leaf, stem and tubers, and collected in paper bags carefully. Then samples were put in electric oven at $70^{\circ} \mathrm{C}$ for drying to obtain a constant dry weight, and finally expressed in $\mathrm{g} /$ plant. 


\section{Tuber bulking rate}

Tuber bulking rate is defined as the increase in fresh weight of tuber per unit area of land per unit change in time and calculated by the following formula:

$$
\operatorname{TBR}\left(\left(\mathrm{g} / \mathrm{m}^{2}\right) / \text { day }\right)=\frac{\mathrm{w} 2-\mathrm{W} 1}{\mathrm{t} 2-\mathrm{t} 1} \mathrm{X} \mathrm{GA}
$$

Where, $\mathrm{W}_{2}$ and $\mathrm{W}_{1}$ are the final and initial fresh weights of tuber per unit area at times $t_{2}$ (final time in days) and $t_{1}$ (initial time in days), respectively and GA is the ground area $\left(\mathrm{m}^{2}\right)$.

\section{Yield of tubers}

The middle two rows of potatoes in each plot were harvested for yield. Fresh weight of tubers (both grade-wise and total) from each plot was taken and finally represented in $\mathrm{t} / \mathrm{ha}$.

\section{Harvest index}

It is the ratio of economic yield (here, tuber yield) to the amount of total biomass produced by the crop. It is an indicator of economic outcome of the farmer and partitioning of dry matter towards the economic parts.

$$
\mathrm{HI}=\frac{\text { Total Tuber Yield }(\mathrm{kg} / \mathrm{ha})}{\text { Total Biomass Yield }(\mathrm{kg} / \mathrm{ha})} X 100
$$

\section{Comparative economics \\ Gross Return}

The gross return was worked out from the total output before deducting the cost of cultivation.

\section{Net Return}

Net return was computed from the total output after deducting the total variable costs which also included the wages of manual labour.

\section{Returns per rupee of investment}

Return per rupee of investment (RRI) was also was worked out by dividing the gross return by the total cost of cultivation.

Returns per rupee of investment above farmer's practice The "returns per rupee of investment above farmer's practice" (RRIFP) is calculated as a percentage of the increment in returns per rupee of investment of a treatment with respect to that of the farmer's practice.

$$
\mathrm{RRIFP}=\frac{\mathrm{RRI} \text { in treatment (rupees) }-\mathrm{RRI} \text { in farmer's practice(rupees) }}{\mathrm{RRI} \text { in farmer's practice (rupees) }} \times 100
$$

\section{Results and discussion \\ Nutrient use efficiency \\ Partial factor productivity}

It was clearly evident from Table 3. that the partial factor productivity was significantly influenced by application of Boron and Zinc.

The partial factor productivity indicates the efficiency with which the input applied can be reflected in the economic yield of the crop. It can be seen that the highest value of PFP for both $\mathrm{Zn}$ and $\mathrm{B}$ of 25.1 were recorded in $\mathrm{T}_{7}(\mathrm{RDF}+$ foliar spray of $0.1 \%$ zinc (zinc sulphate) $+0.1 \%$ boron (boric acid) at 40, 50 and 60 DAP) which indicates that foliar application of the nutrients show higher input use efficiency.

\section{Agronomic efficiency}

Agronomic efficiency gives the rate at increase of unit yield per unit of nutrient applied in comparison to that of the control plot. Trends similar to that of PFP can be noticed in $\mathrm{AE}$ where the highest $\mathrm{AE}$ of 5.73 for both $\mathrm{Zn}$ and $\mathrm{B}$ is also recorded in in $\mathrm{T}_{7}$ (RDF + foliar spray of $0.1 \%$ zinc (zinc sulphate) $+0.1 \%$ boron (boric acid) at 40, 50 and 60 DAP) (Table 4)

However, while comparing the AE of $\mathrm{Zn}$ with that of $\mathrm{B}$, it can be clearly seen that the treatments with the application of $B$ along with the recommended dose of fertilizers showed higher agronomic efficiency to that of application of $\mathrm{Zn}$ along with the recommended dose of fertilizers. This indicates that $\mathrm{B}$ shows better improvement of yield than $\mathrm{Zn}$.

\section{Uptake efficiency}

Nutrient uptake is the percentage of the nutrient content present in the total dry matter of the crop and uptake efficiency gives the rate at which the applied nutrient is converted to the dry matter in a particular treatment compared to that of the control for every unit of nutrient applied in the treatment. Hence, from Table 5 it is indicated that $\mathrm{Zn}$ has better use efficiency than B. The highest UE among $\mathrm{Zn}$ and B is observed for $\mathrm{Zn}$ of $11.61 \%$ in $\mathrm{T}_{7}(\mathrm{RDF}+$ foliar spray of $0.1 \%$ zinc (zinc sulphate) $+0.1 \%$ boron (boric acid) at 40,50 and 60 DAP).

\section{Biomass nutrient use efficiency}

Biomass nutrient use efficiency (BNUE) indicates the incremental biomass yield increase per incremental increase in the plant nutrient uptake. It is evident from Table 6 that both $\mathrm{Zn}$ and $\mathrm{B}$ show the highest value of BNUE of $3.18 \%$ and $12.14 \%$ respectively in $\mathrm{T}_{7}$ ( $\mathrm{RDF}+$ foliar spray of $0.1 \%$ zinc (zinc sulphate) $+0.1 \%$ boron (boric acid) at 40,50 and 60 DAP), which again indicates the superiority of foliar application for better uptake and biomass yield over soil application of the micro- nutrients.

\section{Physiological nutrient use efficiency}

Physiological nutrient use efficiency (PNUE) gives the incremental economical (here, tuber) yield increase per incremental increase in the plant nutrient uptake. As it can be seen from Table 7 the PNUE follows the same trend as that of BNUE in terms of highest value. However, it is interesting to note that the values of PNUE for B is significantly higher than that of $\mathrm{Zn}$ overall. This may be an indication that $\mathrm{B}$ is helpful in increasing the tuber yield of potato by channeling the photosysnthates towards the tubers.

\section{Recovery efficiency}

Recovery efficiency (RE) is the incremental increase in the plant nutrient uptake due to the applied nutrient. It is seen that the RE for both $\mathrm{Zn}$ and B follows the same trend as that of BNUE and PNUE in terms of highest value (Table 8). However, here, $\mathrm{Zn}$ shows better recovery efficiency than B overall. 
Table 3: Partial factor productivity (PFP) of $\mathrm{Zn}$ and $\mathrm{B}$ as influenced by various treatments

\begin{tabular}{|c|c|c|}
\hline Treatments & PFP (Zn) & PFP (B) \\
\hline $\mathrm{T}_{1}\left(\mathrm{RDF}\right.$ of NPK $\left.200: 150: 150 \mathrm{~kg} \mathrm{~N}: \mathrm{P}_{2} \mathrm{O}_{5}: \mathrm{K}_{2} \mathrm{O} / \mathrm{ha}\right)$ & --- & --- \\
\hline $\mathrm{T}_{2}\left(\mathrm{~T}_{1}+2.0 \mathrm{~kg} \mathrm{~B} / \mathrm{ha}\right.$ as soil application $)$ & --- & 13.1 \\
\hline $\mathrm{T}_{3}\left(\mathrm{~T}_{1}+4.5 \mathrm{~kg} \mathrm{Zn} / \mathrm{ha}\right.$ as soil application $)$ & 5.3 & --- \\
\hline $\mathrm{T}_{4}\left(\mathrm{~T}_{1}+2.0 \mathrm{~kg} \mathrm{~B} / \mathrm{ha}\right.$ and $4.5 \mathrm{~kg} \mathrm{Zn} / \mathrm{ha}$ as soil application $)$ & 6.3 & 14.2 \\
\hline $\mathrm{T}_{5}\left(\mathrm{~T}_{1}+0.1 \%\right.$ boron (boric acid) as foliar application in three times at 40,50 and $\left.60 \mathrm{DAP}\right)$ & --- & 23 \\
\hline $\mathrm{T}_{6}\left(\mathrm{~T}_{1}+0.1 \%\right.$ zinc (zinc sulphate) as foliar application in three times at 40,50 and $\left.60 \mathrm{DAP}\right)$ & 20.9 & --- \\
\hline $\mathrm{T}_{7}\left(\mathrm{~T}_{1}+\right.$ Foliar spray of $0.1 \%$ zinc (zinc sulphate) $+0.1 \%$ boron (boric acid) at 40,50 and $\left.60 \mathrm{DAP}\right)$ & 25.1 & 25.1 \\
\hline
\end{tabular}

Table 4: Agronomic efficiency (AE) of $\mathrm{Zn}$ and $\mathrm{B}$ as influenced by various treatments

\begin{tabular}{|c|c|c|}
\hline Treatments & AE (Zn) & AE (B) \\
\hline $\mathrm{T}_{1}\left(\mathrm{RDF}\right.$ of NPK $\left.200: 150: 150 \mathrm{~kg} \mathrm{~N}: \mathrm{P}_{2} \mathrm{O}_{5}: \mathrm{K}_{2} \mathrm{O} / \mathrm{ha}\right)$ & --- & --- \\
\hline $\mathrm{T}_{2}\left(\mathrm{~T}_{1}+2.0 \mathrm{~kg} \mathrm{~B} / \mathrm{ha}\right.$ as soil application $)$ & --- & 1.48 \\
\hline $\mathrm{T}_{3}\left(\mathrm{~T}_{1}+4.5 \mathrm{~kg} \mathrm{Zn} / \mathrm{ha}\right.$ as soil application $)$ & 0.17 & --- \\
\hline $\mathrm{T}_{4}\left(\mathrm{~T}_{1}+2.0 \mathrm{~kg} \mathrm{~B} / \mathrm{ha}\right.$ and $4.5 \mathrm{~kg} \mathrm{Zn} / \mathrm{ha}$ as soil application $)$ & 1.16 & 2.61 \\
\hline $\mathrm{T}_{5}\left(\mathrm{~T}_{1}+0.1 \%\right.$ boron (boric acid) as foliar application in three times at 40,50 and $\left.60 \mathrm{DAP}\right)$ & --- & 3.63 \\
\hline $\mathrm{T}_{6}\left(\mathrm{~T}_{1}+0.1 \%\right.$ zinc (zinc sulphate) as foliar application in three times at 40,50 and $\left.60 \mathrm{DAP}\right)$ & 1.49 & --- \\
\hline $\mathrm{T}_{7}\left(\mathrm{~T}_{1}+\right.$ Foliar spray of $0.1 \%$ zinc (zinc sulphate) $+0.1 \%$ boron (boric acid) at 40,50 and $\left.60 \mathrm{DAP}\right)$ & 5.73 & 5.73 \\
\hline
\end{tabular}

Table 5: Uptake efficiency (UE) of $\mathrm{Zn}$ and $\mathrm{B}$ as influenced by various treatments

\begin{tabular}{|c|c|c|}
\hline Treatments & UE\% (Zn) & $\mathrm{UE} \%(\mathrm{~B})$ \\
\hline 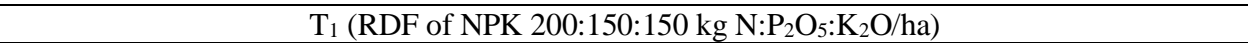 & --- & --- \\
\hline $\mathrm{T}_{2}\left(\mathrm{~T}_{1}+2.0 \mathrm{~kg} \mathrm{~B} / \mathrm{ha}\right.$ as soil application $)$ & --- & 1.03 \\
\hline $\mathrm{T}_{3}\left(\mathrm{~T}_{1}+4.5 \mathrm{~kg} \mathrm{Zn} / \mathrm{ha}\right.$ as soil application $)$ & 1.35 & --- \\
\hline $\mathrm{T}_{4}\left(\mathrm{~T}_{1}+2.0 \mathrm{~kg} \mathrm{~B} / \mathrm{ha}\right.$ and $4.5 \mathrm{~kg} \mathrm{Zn} / \mathrm{ha}$ as soil application $)$ & 2.27 & 1.47 \\
\hline $\mathrm{T}_{5}\left(\mathrm{~T}_{1}+0.1 \%\right.$ boron (boric acid) as foliar application in three times at 40, 50 and $\left.60 \mathrm{DAP}\right)$ & --- & 2.19 \\
\hline $\mathrm{T}_{6}\left(\mathrm{~T}_{1}+0.1 \%\right.$ zinc (zinc sulphate) as foliar application in three times at 40,50 and $\left.60 \mathrm{DAP}\right)$ & 6.58 & --- \\
\hline $\mathrm{T}_{7}\left(\mathrm{~T}_{1}+\right.$ Foliar spray of $0.1 \%$ zinc (zinc sulphate) $+0.1 \%$ boron (boric acid) at 40,50 and $\left.60 \mathrm{DAP}\right)$ & 11.61 & 3.27 \\
\hline
\end{tabular}

Table 6: Biomass nutrient use efficiency (BNUE) of $\mathrm{Zn}$ and B as influenced by various treatments

\begin{tabular}{|c|c|c|}
\hline Treatments & BNUE\% (Zn) & BNUE\% (B) \\
\hline $\mathrm{T}_{1}\left(\mathrm{RDF}\right.$ of NPK $\left.200: 150: 150 \mathrm{~kg} \mathrm{~N}: \mathrm{P}_{2} \mathrm{O}_{5}: \mathrm{K}_{2} \mathrm{O} / \mathrm{ha}\right)$ & --- & --- \\
\hline $\mathrm{T}_{2}\left(\mathrm{~T}_{1}+2.0 \mathrm{~kg} \mathrm{~B} / \mathrm{ha}\right.$ as soil application $)$ & --- & 8.59 \\
\hline $\mathrm{T}_{3}\left(\mathrm{~T}_{1}+4.5 \mathrm{~kg} \mathrm{Zn} / \mathrm{ha}\right.$ as soil application $)$ & 0.41 & --- \\
\hline $\mathrm{T}_{4}\left(\mathrm{~T}_{1}+2.0 \mathrm{~kg} \mathrm{~B} / \mathrm{ha}\right.$ and $4.5 \mathrm{~kg} \mathrm{Zn} / \mathrm{ha}$ as soil application $)$ & 3.11 & 10.82 \\
\hline $\mathrm{T}_{5}\left(\mathrm{~T}_{1}+0.1 \%\right.$ boron (boric acid) as foliar application in three times at 40,50 and $\left.60 \mathrm{DAP}\right)$ & --- & 10.95 \\
\hline $\mathrm{T}_{6}\left(\mathrm{~T}_{1}+0.1 \%\right.$ zinc (zinc sulphate) as foliar application in three times at 40,50 and $\left.60 \mathrm{DAP}\right)$ & 0.86 & --- \\
\hline $\mathrm{T}_{7}\left(\mathrm{~T}_{1}+\right.$ Foliar spray of $0.1 \%$ zinc (zinc sulphate) $+0.1 \%$ boron (boric acid) at 40,50 and $\left.60 \mathrm{DAP}\right)$ & 3.18 & 12.14 \\
\hline
\end{tabular}

Table 7: Physiological nutrient use efficiency (PNUE) of Zn and B as influenced by various treatments

\begin{tabular}{|c|c|c|}
\hline Treatments & PNUE\% (Zn) & PNUE\% (B) \\
\hline $\mathrm{T}_{1}\left(\mathrm{RDF}\right.$ of NPK $\left.200: 150: 150 \mathrm{~kg} \mathrm{~N}: \mathrm{P}_{2} \mathrm{O}_{5}: \mathrm{K}_{2} \mathrm{O} / \mathrm{ha}\right)$ & --- & --- \\
\hline $\mathrm{T}_{2}\left(\mathrm{~T}_{1}+2.0 \mathrm{~kg} \mathrm{~B} / \mathrm{ha}\right.$ as soil application $)$ & --- & 14.39 \\
\hline $\mathrm{T}_{3}\left(\mathrm{~T}_{1}+4.5 \mathrm{~kg} \mathrm{Zn} / \mathrm{ha}\right.$ as soil application $)$ & 1.23 & --- \\
\hline $\mathrm{T}_{4}\left(\mathrm{~T}_{1}+2.0 \mathrm{~kg} \mathrm{~B} / \mathrm{ha}\right.$ and $4.5 \mathrm{~kg} \mathrm{Zn} / \mathrm{ha}$ as soil application $)$ & 5.11 & 17.78 \\
\hline $\mathrm{T}_{5}\left(\mathrm{~T}_{1}+0.1 \%\right.$ boron (boric acid) as foliar application in three times at 40,50 and $\left.60 \mathrm{DAP}\right)$ & --- & 16.54 \\
\hline $\mathrm{T}_{6}\left(\mathrm{~T}_{1}+0.1 \%\right.$ zinc (zinc sulphate) as foliar application in three times at 40,50 and $\left.60 \mathrm{DAP}\right)$ & 2.27 & --- \\
\hline $\mathrm{T}_{7}\left(\mathrm{~T}_{1}+\right.$ Foliar spray of $0.1 \%$ zinc (zinc sulphate) $+0.1 \%$ boron (boric acid) at 40,50 and $\left.60 \mathrm{DAP}\right)$ & 4.93 & 18.82 \\
\hline
\end{tabular}

Table 8: Recovery efficiency (RE) of $\mathrm{Zn}$ and $\mathrm{B}$ as influenced by various treatments

\begin{tabular}{|c|c|c|}
\hline Treatments & RE\% (Zn) & RE\% (B) \\
\hline $\mathrm{T}_{1}\left(\mathrm{RDF}\right.$ of NPK $\left.200: 150: 150 \mathrm{~kg} \mathrm{~N}: \mathrm{P}_{2} \mathrm{O}_{5}: \mathrm{K}_{2} \mathrm{O} / \mathrm{ha}\right)$ & --- & --- \\
\hline $\mathrm{T}_{2}\left(\mathrm{~T}_{1}+2.0 \mathrm{~kg} \mathrm{~B} / \mathrm{ha}\right.$ as soil application $)$ & --- & 1.03 \\
\hline $\mathrm{T}_{3}\left(\mathrm{~T}_{1}+4.5 \mathrm{~kg} \mathrm{Zn} / \mathrm{ha}\right.$ as soil application $)$ & 1.35 & --- \\
\hline $\mathrm{T}_{4}\left(\mathrm{~T}_{1}+2.0 \mathrm{~kg} \mathrm{~B} / \mathrm{ha}\right.$ and $4.5 \mathrm{~kg} \mathrm{Zn} / \mathrm{ha}$ as soil application $)$ & 2.27 & 1.47 \\
\hline $\mathrm{T}_{5}\left(\mathrm{~T}_{1}+0.1 \%\right.$ boron (boric acid) as foliar application in three times at 40,50 and $\left.60 \mathrm{DAP}\right)$ & --- & 2.19 \\
\hline $\mathrm{T}_{6}\left(\mathrm{~T}_{1}+0.1 \%\right.$ zinc (zinc sulphate) as foliar application in three times at 40,50 and $\left.60 \mathrm{DAP}\right)$ & 6.58 & --- \\
\hline $\mathrm{T}_{7}\left(\mathrm{~T}_{1}+\right.$ Foliar spray of $0.1 \%$ zinc (zinc sulphate) $+0.1 \%$ boron (boric acid) at 40,50 and $\left.60 \mathrm{DAP}\right)$ & 11.61 & 3.04 \\
\hline
\end{tabular}

\section{Yield attributes}

\section{Total dry matter (DM) production}

It was clearly evident from Table 9 that the total dry matter production of potato at various stages of crop growth was significantly influenced by application of Boron and Zinc.
It was revealed that up to $50 \mathrm{DAP}$, the total dry matter production varied significantly from 546.20 to $619.40 \mathrm{~g} / \mathrm{m}^{2}$ due to application of different treatments. The highest total dry matter production up to 50 DAP $\left(619.40 \mathrm{~g} / \mathrm{m}^{2}\right)$ was recorded in the treatment $\mathrm{T}_{4}(\mathrm{RDF}$ of $\mathrm{NPK}+2.0 \mathrm{~kg} \mathrm{~B} / \mathrm{ha}$ and 
$4.5 \mathrm{~kg} \mathrm{Zn} / \mathrm{ha}$ as soil application) which was found statistically at par with the treatment $\mathrm{T}_{7}$ (RDF + foliar spray of $0.1 \%$ zinc (zinc sulphate) $+0.1 \%$ boron (boric acid) at 40, 50 and 60 DAP). The lowest total dry matter production up to 50 DAP $\left(546.20 \mathrm{~g} / \mathrm{m}^{2}\right)$ was recorded in the treatment $\mathrm{T}_{1}$ (RDF of NPK).

However, at 65 DAP, the total dry matter production varied significantly from 845.23 to $965.65 \mathrm{~g} / \mathrm{m}^{2}$ due to application of different treatments. The highest total dry matter production at 65 DAP $\left(968.93 \mathrm{~g} / \mathrm{m}^{2}\right)$ was recorded in the treatment $\mathrm{T}_{7}$ $(\mathrm{RDF}+$ foliar spray of $0.1 \%$ zinc (zinc sulphate) $+0.1 \%$ boron (boric acid) at 40, 50 and 60 DAP) which was found statistically at par with the treatment $\mathrm{T}_{4}(\mathrm{RDF}$ of NPK+2.0 kg $\mathrm{B} / \mathrm{ha}$ and $4.5 \mathrm{~kg} \mathrm{Zn/ha}$ as soil application). The lowest total dry matter production up to 65 DAP $\left(845.23 \mathrm{~g} / \mathrm{m}^{2}\right)$ was recorded in the treatment $\mathrm{T}_{1}$ (RDF of NPK).

It was observed that at $80 \mathrm{DAP}$, the total dry matter production varied significantly from 980.64 to $1121.80 \mathrm{~g} / \mathrm{m}^{2}$ due to application of different treatments. The highest total dry matter production at 80 DAP $\left(1126.05 \mathrm{~g} / \mathrm{m}^{2}\right)$ was recorded in the treatment $\mathrm{T}_{7}(\mathrm{RDF}+$ foliar spray of $0.1 \%$ zinc (zinc sulphate) $+0.1 \%$ boron (boric acid) at 40, 50 and 60 DAP) which was found statistically at par with the treatment $\mathrm{T}_{4}$ (RDF of $\mathrm{NPK}+2.0 \mathrm{~kg} \mathrm{~B} / \mathrm{ha}$ and $4.5 \mathrm{~kg} \mathrm{Zn} / \mathrm{ha}$ as soil application) which might be due to higher uptake of nutrients, better source to sink relation and higher translocation of starch. The lowest total dry matter production at 80 DAP $\left(980.64 \mathrm{~g} / \mathrm{m}^{2}\right)$ was recorded in the treatment $\mathrm{T}_{1}$ (RDF of NPK).

\section{Tuber bulking rate (TBR)}

It was clearly evident from Table 10 that the tuber bulking rate of potato was significantly influenced by application of Boron and Zinc.

It was observed that from 50 to 65 DAP, the tuber bulking rate varied significantly from 17.60 to $20.15 \mathrm{~g} \mathrm{~m}^{-2}$ day $^{-1}$ due to application of different treatments. The highest tuber bulking rate from 50 to 65 DAP $\left(20.22 \mathrm{~g} \mathrm{~m}^{-2}\right.$ day $\left.^{-1}\right)$ was observed in the treatment $\mathrm{T}_{7}(\mathrm{RDF}+$ foliar spray of $0.1 \%$ zinc (zinc sulphate) $+0.1 \%$ boron (boric acid) at 40,50 and 60 DAP) which was found statistically at par with the treatments $\mathrm{T}_{4}$ (RDF of $\mathrm{NPK}+2.0 \mathrm{~kg} \mathrm{~B} / \mathrm{ha}$ and $4.5 \mathrm{~kg} \mathrm{Zn/ha}$ as soil application) and $\mathrm{T}_{5}$ (RDF of NPK $+0.1 \%$ boric acid as foliar application in three times at 40,50 and $60 \mathrm{DAP})$. The lowest tuber bulking rate from 50 to 65 DAP $\left(17.62 \mathrm{~g} \mathrm{~m}^{-2}\right.$ day $\left.^{-1}\right)$ was found in $\mathrm{T}_{1}$ (RDF of NPK).

It was observed that from 65 to $80 \mathrm{DAP}$, the tuber bulking rate varied significantly from 8.64 to $9.48 \mathrm{~g} \mathrm{~m}^{-2}$ day $^{-1}$ due to application of different treatments. The highest tuber bulking rate $\left(9.48 \mathrm{~g} \mathrm{~m}^{-2} \mathrm{day}^{-1}\right)$ from 65 to 80 DAP was observed in the treatment $\mathrm{T}_{7}(\mathrm{RDF}+$ foliar spray of $0.1 \%$ zinc (zinc sulphate) $+0.1 \%$ boron (boric acid) at 40, 50 and 60 DAP) which was found statistically at par with the treatment $\mathrm{T}_{4}$ (RDF of $\mathrm{NPK}+2.0 \mathrm{~kg} \mathrm{~B} / \mathrm{ha}$ and $4.5 \mathrm{~kg} \mathrm{Zn} / \mathrm{ha}$ as soil application). The lowest tuber bulking rate from 65 to $80 \mathrm{DAP}\left(8.67 \mathrm{~g} \mathrm{~m}^{-2}\right.$ day ${ }^{1}$ ) was recorded in $\mathrm{T}_{1}$ (RDF of NPK).

\section{Harvest index}

It was clearly evident from Table 11 that the total tuber yield of potato variety Kufri Jyoti was significantly influenced by application of Boron and Zinc over RDF.

It was observed that the harvest index varied significantly from 73.18 to $83.20 \%$ due to application of different treatments. The highest harvest index of $83.20 \%$ was recorded in the treatment $\mathrm{T}_{7}(\mathrm{RDF}+$ foliar spray of $0.1 \%$ zinc (zinc sulphate) $+0.1 \%$ boron (boric acid) at 40,50 and 60 DAP) which was found statistically at par with the treatment $\mathrm{T}_{4}$ (RDF of $\mathrm{NPK}+2.0 \mathrm{~kg} \mathrm{~B} / \mathrm{ha}$ and $4.5 \mathrm{~kg} \mathrm{Zn} / \mathrm{ha}$ as soil application) which might be due to the fact that $\mathrm{B}$ and $\mathrm{Zn}$ helped in increasing the average weight of individual tubers thereby increasing the tuber number in the medium and large grades (Lenka and Das, 2019) ${ }^{[16]}$ and as such the tuber yield due to increased translocation of starch from source to sink. Similar findings were also reported by Sharma et al. (1988) ${ }^{[22]}$, Uppal and Singh (1989) [26], Das and Jena (1973) [4], Rashid et al. (2007) ${ }^{[21]}$, Singh et al. (2013) ${ }^{[23]}$ and Singh et al. (2014) ${ }^{[24]}$. The lowest harvest index of $73.18 \%$ was recorded in the treatment $\mathrm{T}_{1}(\mathrm{RDF}$ of NPK).

Table 9: Total dry matter production (DM) of potato as influenced by Boron \& Zinc application

\begin{tabular}{|c|c|c|c|}
\hline \multirow{2}{*}{ Treatments } & \multicolumn{3}{|c|}{ DM $\left(\mathrm{g} / \mathrm{m}^{2}\right)$ at different DAP } \\
\hline & 50 DAP & 65 DAP & 80 DAP \\
\hline $\mathrm{T}_{1}\left(\mathrm{RDF}\right.$ of NPK 200:150:150 kg N:P $\left.\mathrm{P}_{2} \mathrm{O}_{5}: \mathrm{K}_{2} \mathrm{O} / \mathrm{ha}\right)$ & 546.20 & 845.23 & 980.64 \\
\hline $\mathrm{T}_{2}\left(\mathrm{~T}_{1}+2.0 \mathrm{~kg} \mathrm{~B} / \mathrm{ha}\right.$ as soil application $)$ & 565.25 & 877.50 & 1027.90 \\
\hline $\mathrm{T}_{3}\left(\mathrm{~T}_{1}+4.5 \mathrm{~kg} \mathrm{Zn} / \mathrm{ha}\right.$ as soil application $)$ & 554.20 & 858.23 & 998.54 \\
\hline $\mathrm{T}_{4}\left(\mathrm{~T}_{1}+2.0 \mathrm{~kg} \mathrm{~B} / \mathrm{ha}\right.$ and $4.5 \mathrm{~kg} \mathrm{Zn} / \mathrm{ha}$ as soil application $)$ & 619.40 & 938.50 & 1095.60 \\
\hline $\mathrm{T}_{5}\left(\mathrm{~T}_{1}+0.1 \%\right.$ boron (boric acid) as foliar application in three times at 40,50 and $\left.60 \mathrm{DAP}\right)$ & 570.50 & 925.25 & 1083.30 \\
\hline $\mathrm{T}_{6}\left(\mathrm{~T}_{1}+0.1 \%\right.$ zinc (zinc sulphate) as foliar application in three times at 40,50 and $\left.60 \mathrm{DAP}\right)$ & 551.85 & 864.50 & 1010.50 \\
\hline $\mathrm{T}_{7}\left(\mathrm{~T}_{1}+\right.$ Foliar spray of $0.1 \%$ zinc (zinc sulphate) $+0.1 \%$ boron (boric acid) at 40,50 and 60 DAP) & 615.42 & 965.65 & 1121.80 \\
\hline
\end{tabular}

Table 10: Tuber bulking rate (TBR) of potato as influenced by Boron \& Zinc application

\begin{tabular}{|c|c|c|}
\hline \multirow{2}{*}{ Treatments } & \multicolumn{2}{|c|}{ Tuber bulking rate (TBR) $\left(\mathrm{g} \mathrm{m}^{-2}\right.$ day $\left.^{-1}\right)$} \\
\hline & 50-65 DAP & 65-80 DAP \\
\hline $\mathrm{T}_{1}\left(\mathrm{RDF}\right.$ of NPK 200:150:150 kg N:P $\left.\mathrm{O}_{5}: \mathrm{K}_{2} \mathrm{O} / \mathrm{ha}\right)$ & 17.60 & 8.64 \\
\hline $\mathrm{T}_{2}\left(\mathrm{~T}_{1}+2.0 \mathrm{~kg} \mathrm{~B} / \mathrm{ha}\right.$ as soil application $)$ & 18.80 & 9.00 \\
\hline $\mathrm{T}_{3}\left(\mathrm{~T}_{1}+4.5 \mathrm{~kg} \mathrm{Zn} / \mathrm{ha}\right.$ as soil application $)$ & 17.78 & 8.74 \\
\hline $\mathrm{T}_{4}\left(\mathrm{~T}_{1}+2.0 \mathrm{~kg} \mathrm{~B} / \mathrm{ha}\right.$ and $4.5 \mathrm{~kg} \mathrm{Zn} / \mathrm{ha}$ as soil application $)$ & 19.36 & 9.20 \\
\hline $\mathrm{T}_{5}\left(\mathrm{~T}_{1}+0.1 \%\right.$ boron (boric acid) as foliar application in three times at 40,50 and $\left.60 \mathrm{DAP}\right)$ & 19.01 & 9.12 \\
\hline $\mathrm{T}_{6}\left(\mathrm{~T}_{1}+0.1 \%\right.$ zinc (zinc sulphate) as foliar application in three times at 40,50 and $\left.60 \mathrm{DAP}\right)$ & 17.98 & 8.90 \\
\hline $\mathrm{T}_{7}\left(\mathrm{~T}_{1}+\right.$ Foliar spray of $0.1 \%$ zinc (zinc sulphate) $+0.1 \%$ boron (boric acid) at 40,50 and $\left.60 \mathrm{DAP}\right)$ & 20.15 & 9.48 \\
\hline
\end{tabular}


Table 11: Harvest index (HI) of potato as influenced by Boron \& Zinc application

\begin{tabular}{|c|c|}
\hline Treatments & HI \% \\
\hline $\mathrm{T}_{1}\left(\mathrm{RDF}\right.$ of NPK 200:150:150 kg N: $\left.\mathrm{P}_{2} \mathrm{O}_{5}: \mathrm{K}_{2} \mathrm{O} / \mathrm{ha}\right)$ & 73.18 \\
\hline $\mathrm{T}_{2}\left(\mathrm{~T}_{1}+2.0 \mathrm{~kg} \mathrm{~B} / \mathrm{ha}\right.$ as soil application $)$ & 78.14 \\
\hline $\mathrm{T}_{3}\left(\mathrm{~T}_{1}+4.5 \mathrm{~kg} \mathrm{Zn} / \mathrm{ha}\right.$ as soil application $)$ & 74.95 \\
\hline $\mathrm{T}_{4}\left(\mathrm{~T}_{1}+2.0 \mathrm{~kg} \mathrm{~B} / \mathrm{ha}\right.$ and $4.5 \mathrm{~kg} \mathrm{Zn} / \mathrm{ha}$ as soil application $)$ & 81.45 \\
\hline $\mathrm{T}_{5}\left(\mathrm{~T}_{1}+0.1 \%\right.$ boron (boric acid) as foliar application in three times at 40,50 and $\left.60 \mathrm{DAP}\right)$ & 79.65 \\
\hline $\mathrm{T}_{6}\left(\mathrm{~T}_{1}+0.1 \%\right.$ zinc (zinc sulphate) as foliar application in three times at 40,50 and $\left.60 \mathrm{DAP}\right)$ & 77.16 \\
\hline $\mathrm{T}_{7}\left(\mathrm{~T}_{1}+\right.$ Foliar spray of $0.1 \%$ zinc (zinc sulphate) $+0.1 \%$ boron (boric acid) at 40,50 and $\left.60 \mathrm{DAP}\right)$ & 83.20 \\
\hline
\end{tabular}

\section{Comparative economics}

Returns per rupee of investment above farmer's practice It is sometimes seen in many field experiments that a particular treatment doesn't show significant economic gain over the existing farmer's practice. However, implementing the treatment in larger scales can alleviate the existing problems in the farmer's field. In this situation, it is important to quantify by how much a treatment contributes to better economic gains. Hence, calculating the "Returns per rupee of investment above farmer's practice" (RRIFP) serves the purpose. This will not only point out the best treatment in terms of economic gains, but also tell us by how much is it better than the existing farmer's practice in percentage in terms of remuneration. The percentage of economic gain over the farmer's practice gives us an accurate guide by which it can be extrapolated according to the area, extent and volume of the production and helps us in finding the actual gain in the farmer's field by implementing the treatment. This can also be used to find out the profitability of various combinations of the treatment in a simple manner using the existing data before implementing it on a larger scale.

It can be observed from Table 12, that the highest RRIFP of $28.5 \%$ is recorded in $\mathrm{T}_{7}$ ( $\mathrm{RDF}+$ foliar spray of $0.1 \%$ zinc (zinc sulphate) $+0.1 \%$ boron (boric acid) at 40,50 and 60 DAP) and the lowest RRIFP value of $0.7 \%$ is recorded in $\mathrm{T}_{3}$ $(\mathrm{RDF}+4.5 \mathrm{~kg} \mathrm{Zn} / \mathrm{ha}$ as soil application). This shows the extent to which a particular treatment is helpful in giving remunerative gains to the farmer per unit of input used in addition to the existing practice followed.

Table 12: Comparative economics of potato as influenced by Boron $\&$ Zinc application

\begin{tabular}{|c|c|c|c|c|}
\hline Treatments & $\begin{array}{l}\text { Gross Returns } \\
\text { (Rs./ha) }\end{array}$ & \begin{tabular}{|c|} 
Net Returns \\
(Rs./ha)
\end{tabular} & \begin{tabular}{c|c|} 
RRI \\
(Rs./ha)
\end{tabular} & \begin{tabular}{|l|} 
RRIF \\
P (\%) \\
\end{tabular} \\
\hline $\mathrm{T}_{1}\left(\mathrm{RDF}\right.$ of NPK $\left.200: 150: 150 \mathrm{~kg} \mathrm{~N}: \mathrm{P}_{2} \mathrm{O}_{5}: \mathrm{K}_{2} \mathrm{O} / \mathrm{ha}\right)$ & 139500 & 42886 & 1.44 & --- \\
\hline $\mathrm{T}_{2}\left(\mathrm{~T}_{1}+2.0 \mathrm{~kg} \mathrm{~B} / \mathrm{ha}\right.$ as soil application $)$ & 157200 & 58919 & 1.60 & 11.1 \\
\hline $\mathrm{T}_{3}\left(\mathrm{~T}_{1}+4.5 \mathrm{~kg} \mathrm{Zn} / \mathrm{ha}\right.$ as soil application $)$ & 144000 & 44601 & 1.45 & 0.7 \\
\hline $\mathrm{T}_{4}\left(\mathrm{~T}_{1}+2.0 \mathrm{~kg} \mathrm{~B} / \mathrm{ha}\right.$ and $4.5 \mathrm{~kg} \mathrm{Zn} / \mathrm{ha}$ as soil application $)$ & 171760 & 70695 & 1.70 & 18.1 \\
\hline $\mathrm{T}_{5}\left(\mathrm{~T}_{1}+0.1 \%\right.$ boron (boric acid) as foliar application in three times at 40,50 and $\left.60 \mathrm{DAP}\right)$ & 166600 & 69269 & 1.71 & 18.7 \\
\hline $\mathrm{T}_{6}\left(\mathrm{~T}_{1}+0.1 \%\right.$ zinc (zinc sulphate) as foliar application in three times at 40, 50 and $\left.60 \mathrm{DAP}\right)$ & 150240 & 52766 & 1.54 & 6.9 \\
\hline $\begin{array}{c}\mathrm{T}_{7}\left(\mathrm{~T}_{1}+\text { Foliar spray of } 0.1 \% \text { zinc (zinc sulphate) }+0.1 \% \text { boron (boric acid) at } 40,50 \text { and } 60\right. \\
\text { DAP) }\end{array}$ & 180720 & 83189 & 1.85 & 28.5 \\
\hline
\end{tabular}

\section{Conclusions}

In modern agriculture, micronutrients are becoming deficient day-by-day due to intensive cultivation with high yielding varieties of crops \& use of high analysis fertilizers. In India, potato being a cash crop, occupies a unique place due to its high nutritional value.

It can be observed that the highest value of PFP, AE, UE, BNUE, PNUE and RE for both $\mathrm{Zn}$ and $\mathrm{B}$ of were recorded in $\mathrm{T}_{7}(\mathrm{RDF}+$ foliar spray of $0.1 \%$ zinc (zinc sulphate) $+0.1 \%$ boron (boric acid) at 40, 50 and 60 DAP). The same trend was found in both harvest index and returns per rupee of investment above farmer's practice.

It was observed that the effect of Boron in increasing tuber yield of potato was found more pronounced than Zinc under this experimental situation. However, foliar application of $\mathrm{B}$ $\& \mathrm{Zn}$ was found superior to all the treatments including soil application in the experiment in increasing all the yield attributes of potato, thereby giving better remunerative returns to the farmer.

\section{Future scope of research}

Till date numerous studies have been conducted on yield response of potato to macronutrients (N, P \& K mainly). So, more research on other micronutrients like $\mathrm{Mn}, \mathrm{Fe}, \mathrm{Cu}$ etc. should be done. More detailed study on bio-chemical parameters of potato should be studied like TSS, total lipid content etc. The present study was carried out with one potato cultivar 'Kufri Jyoti'. The response of other potato cultivars to Zinc \& Boron should be studied. More detailed study on foliar application of micronutrients should be done.

\section{References}

1. Cakmak I. Possible roles of Zinc in protecting plant cells from damage by reactive oxygen species. New Phytol. 2000; 146:185-205.

2. Cassman KG, Peng S, Olek DC, Ladha JK, Reichhardt $\mathrm{W}$, Dobermann A et al. Opportunities for increased nitrogen use efficiency from improved resource management in irrigated rice systems. Field Crops Research. 1998; 56:7-19.

3. Craswell T, Godwin DC. The efficiency of $\mathrm{N}$ fertilizers applied to cereals in different climates. In Advances in plant nutrition, ed. P. B. Tnker, and A. Lauchli, New York: Praeger, 1984, 1-55.

4. Das RC, Jena MK. Studies on effect of soil application of Molybdenum, Boron and paper mill sludge on the postharvest qualities of potato tubers (Solanum tuberosum L.). Madras Agricultural Journal. 1973; 60:1026-1029.

5. Dugger WM. Adv. Chem. Ser. 1973; 123:112-129.

6. Donald CM, Hamblin J. The Biological Yield and Harvest Index of Cereals as Agronomic and Plant Breeding Criteria. Advances in Agronomy. 1976; 28:361405. 
7. Eide DJ. Homeostatic and adaptive responses to Zinc deficiency in Saccharomyces cerevisiae. J. Biol. Chem. 2009; 284:18565-18569.

8. Grewal JS, Trehan SP. Micronutrients requirements of potato crop. Annual Scientific Report, CPRI, Shimla, 1979, 49-50.

9. Grotz N, Guerinot ML. Molecular aspects of $\mathrm{Cu}, \mathrm{Fe}$ and $\mathrm{Zn}$ homeostasis in plants. Biochimica et Biophysica Acta. 2006; 1763(7):595-608.

10. Gupta UC. Some factors affecting the determination of hot water-soluble Boron from podzol soil, 1979.

11. Hansch R, Mendel RR. Physiological functions of mineral micronutrients $(\mathrm{Cu}, \mathrm{Zn}, \mathrm{Mn}, \mathrm{Fe}, \mathrm{Ni}, \mathrm{Mo}, \mathrm{B}, \mathrm{Cl})$. Curr. Opin. Plant Biol. 2009; 12:259-266.

12. Jackson NL. Soil chemical analysis. Prentice Hall of India Ltd., New Delhi, India, 1967.

13. Kawachi M, Kobae Y, Mori H, Tomioka R, Lee Y, Maeshima M. A mutant strain Arabidopsis thaliana that lacks vacuolar membrane Zinc transporter MTP1 revealed the latent tolerance to excessive Zinc. Plant Cell Physiol. 2009; 50:1156-1170.

14. Lee S, Kim SA, Lee J, Guerinot ML, An G. Zinc deficiency inducible osZIP8 encodes a plasma membrane-localized Zinc transporter in rice. Mol. cells. 2010; 29:551-558.

15. Lindsay WL, Norvell WA. Development of a DTPA soil test for Zinc, Iron, Manganese and Copper. Soil Science Society of American Journal. 1978; 42:421-428.

16. Lenka Biswajit, Das Sanjib. Effect of boron and zinc application on growth and productivity of potato (Solanum tuberosum) at alluvial soil (Entisols) of India. Indian Journal of Agronomy. 2019; 64:129-137. 10.13140/RG.2.2.32991.00165.

17. Mengel K, Kirkby EA. Principles of Plant Nutrition. International Potash Institute, Bern, Switzerland, 1978.

18. Novoa R, Loomis RS. Nitrogen and plant production. Plant Soil. 1981; 58:177-204.

19. Palmer CM, Guerinot ML. Facing the challenges of $\mathrm{Cu}$, Fe and Zn homeostasis in plants. Nat. Chem. Biol. 2009; 5:333-340.

20. Piper CS. Soil and Plant Analysis. Academic Press, New York, 1966.

21. Rashid A, Masud MM, Rafique E, Farooq K. Potato responses to Boron and Zinc application in a calcareous udic ustochrept. Advances in Plant and Animal Boron nutrition, Springer, 2007, 137-142.

22. Sharma UC, Grewal JS, Trehan SP. Response of potato to applied zinc on soils with variable zinc availability. J. Indian Potato Assoc. 1988; 15(1-2):21-26.

23. Singh A, Singh RA, Yadav D. Studies of Boron use in nutrients deficient area for enhancing the tubers yield of potato. The Asian Journal of Horticulture. 2013; $8(1): 381-382$.

24. Singh S, Kumar D, Chandel BS, Singh V. Effect of balanced fertilization on yield, nutrients uptake and economics of potato (Solanum tuberosum) in alluvial soil. Indian Journal of Agronomy. 2014; 59(3):451-454.

25. Trehan SP, Grewal JS. Comparitive efficiency of methods of application of Zinc to potato. Ind. J. Agric. Sci. 1981; 51:240-243.

26. Uppal DS, Singh S. Effects of Zinc and Manganese on the photosynthetic rate and translocation of sugars in potato (Solanum tuberosum L.). Journal Nuclear Agriculture and Biology. 1989; 18:64-66.
27. Walkley AJ, Black IA. Method for determining soil organic matter and proposed modification of chromic acid titration method. Soil Science. 1934; 37:29-39.

28. Wolf B. The determination of Boron in soil extracts, plant materials, compost, manures, water and nutrient solutions. Commun Soil Sci. Plant Anal. 1971; 2:363374. 